\title{
TINDAKAN MENYAMARKAN IDENTITAS PELAKU KEJAHATAN (Tinjauan Undang-Undang Nomor 40 Tentang Pers dan KUHP)
}

\author{
Orin Gusta Andini \\ Mahasiswa Program Magister Hukum, Universitas Hasanuddin \\ Email:orinhukumunhas@gmail.com
}

\begin{abstract}
The purpose of this research is to know the vague of crime perpetrator identity by journalist from law number 40/1990 on Pers and Penal Code Perspective and to know the rule of police in enforcing the law related to vague of crime perpetrator identity in observuing journalist investigation result. The type of this research field is filed research in which data collection done by interviewing several parties related to research. Besides, writer also make literature research through related data and books. Then, data taken is analysed qualitatively and explained descriptively.Based on analysis, writer conclude that: very side interpretation on rejection right is legal weakness that can be used by journalist to do action which vague identity if crime perpetrator. The action of vague crime perpetrator identity fey on Artivle 165 Indonesia Penal Code which oblige every citizen to report known to police officer. The usage of rejection right by journalist not suit to article 165 Indonesia Penal Code that can be used to vague informan identity who is witness, child crime perpetrator and rape victim as journalist ethic code.
\end{abstract}

Keywords: The Vague of Perpetrator Identity, Journalist, Law Number 40/1999 on Pers, Indonesian Penal Code.

\section{PENDAHULUAN}

Kemerdekaan pers di Indonesia mulai menjadi agenda penting sejak tahun 1998 dalam mengawal era reformasi pasca berakhirnya kekuasaan Presiden Soeharto. Legitimasi kemerdekaan pers menjadi konsekuensi logis lahirnya Undang-Undang No. 40 Tahun 1999 tentang Pers (UU Pers).Dalam Pasal 1 Ayat (1) UU Persmenyatakan bahwa:

Pers adalah lembaga sosial dan wahana komunikasi massa yang melaksanakan kegiatan jurnalistik meliputi mencari, memperoleh, memiliki, menyimpan, mengolah, dan menyampaikan informasi baik dalam bentuk tulisan, suara, gambar, suara dan gambar, serta data dan grafik maupun dalam bentuk lainnya dengan menggunakan media cetak, media elektronik, dan segala jenis saluranyang tersedia.

Sejak diberlakukannya UU Pers maka secara otomatis negara tidak lagi memiliki kontrol terhadap media (non-state regime), sebab pendirian usaha pers tidak lagi membutuhkan Surat Izin Usaha Pendirian Pers (SIUPP) dari pemerintah. Hilangnya kontrol total pemerintah terhadap pers telah mendorong lahirnya liberalisasi media di 
Indonesia. Akibat dari liberalisasi media, saat ini siapa saja dapat mendirikan perusahaan pers asalkan memiliki modal yang cukup. Padahal pers memiliki kedudukan dan peran yang penting dalam suatu negara. Pers menjadi pilar ke-empat dalam negara berpaham demokrasi. Liberalisasi media di Indonesia telah memberikan perubahan atas paradigma fungsi pers. Pada hakikatnya fungsi pers atau media di Indonesia adalah sebagai wahana informasi, pendidikan, kontrol sosial, dan hiburan (Lihat Pasal 3 ayat (1) dan (2) UU Pers).

Dengan perubahan dan perkembangan pers yang semakin kompleks mengakibatkan paradigma berpikir akan kemustahilan media untuk bertahan tanpa modal yang memadai, maka mendorong fungsi pers bertambah sebagai lembaga ekonomi. Prinsip ekonomi yang mementingkan keuntungan finansial menjadi keharusan untuk dilakukan pers jika ingin medianya bertahan. Akibatnya, kondisi ini menempatkan standar ganda bagi pers dalam mewujudkan cita-cita nasional dalam mencerdaskan kehidupan bangsa dan ikut melaksanakan ketertiban dunia. Media yang terlibas oleh kekuatan liberal adalah stasiun televisi. Pascagerakan reformasi tahun 1998, kepemilikan stasiun televisi telah berubah dari awalnya dimiliki oleh pemerintah (TVRI) saat ini dimiliki dan dikontrol oleh pihak swasta (Lihat Pasal 13 Undang-Undang No. 32 Tahun 2002 tentang Penyiaran).

Kondisi tersebut menyebabkan banyak stasiun televisi swasta yang bersifat komersial bermunculan dan bersaing untuk mendapatkan perhatian pemirsa televisi yang semakin hari semakin beragam. Sumber utama pembiayaan lembaga penyiaran swasta diperoleh dari siaran iklan. Pihak yang ingin memasang iklan melalui media televisi lazim menempatkan iklan yang ingin dikenalkan kepada masyarakat pada acara atau program televisi yang dinilai memiliki penonton yang banyak atau sangat diminati sehingga memiliki rating yang tinggi.Hal itu menyebabkan pihak stasiun televisi bersaing untuk mendapatkan pemasok iklan dengan menciptakan tayangan unggulan menarik yang diminati masyarakat.

Salah satu tayangan unggulan menarik tersebut adalah tayangan bertema investigasi criminal (Diakses melalui http://agbnielsen.co.id, pada 8 September 2014).Tayangan bertema investigasi kriminal adalah sebuah tayangan yang mengungkapkan kejahatan terhadap kepentingan publik, atau tindakan yang merugikan orang lain dengan mencari bukti-bukti yang dilakukan oleh wartawan. Wartawan dalam program investigasi kriminal memiliki tugas untuk menelusuri suatu kejahatan yang belum terungkap dalam kehidupan sehari-hari.Hasil dari penelusuran wartawan berupa tayangan yang semata-mata ditujukan untuk memenuhi episode tayangan bertema investigasi kriminal. Sebenarnya berita mengenai investigasi kiriminal juga diperlukan masyarakat, yang salah satunya berfungsi untuk mengetahui kejahatan apa yang sedang marak terjadi sehingga masyarakat dapat mengantisipasi terhadap kejahatan itu.Hal itu pula yang menyebabkan tayangan bertema investigasi kriminal sangat diminati masyarakat sehingga memiliki rating tayangan yang tinggi.

Dalam tayangan bertema investigasi kriminal, wartawan juga melakukan wawancara secara langsung terhadap pelaku kejahatan.Hasil wawancara tersebut ditayangkan dengan menyamarkan wajah, suara, dan identitas pelaku kejahatan.Tindakan menyamarkan pelaku kejahatan oleh wartawan dilakukan dengan berpedoman pada hak tolak yang dinyatakan dalam Pasal 4 ayat (4) UU Pers dan Pasal 7 Kode Etik Jurnalistik. Pasal 4 ayat (4) UU Pers 
yang menyatakan bahwa dalam mempertanggungjawabkan pemberitaan di depan hukum, wartawan mempunyai hak tolak. Hak tolak adalah hak wartawan karena profesinya untuk menolak mengungkapkan nama atau identitas lainnya dari sumber berita yang dirahasiakannya (Lihat Pasal 1 Angka 10 UU Pers).

Kode Etik Jurnalistik sebagai pedoman wartawan dalam menjalankan profesinya juga menyatakan hak tolak adalah untuk melindungi narasumber yang tidak bersedia diketahui identitas maupun keberadaannya.Dalam kaitannya pada tindakan wartawan menyamarkan wajah, suara, dan identitas pelaku kejahatan tersebut, jika ditinjau melalui ketentuan yang terdapat dalam Kitab Undang-Undang Hukum Pidana (KUHP), maka secara tidak langsung sebenarnya tindakan wartawan yang menyamarkan identitas pelaku kejahatan telah bertentangan dengan Pasal 165 KUHP yang mewajibkan bagi setiap warga negara yang mengetahui adanya kejahatan yang dilakukan oleh orang lain untuk segera melapor kepada kepolisian atau pejabat yang berwenang.

Kejahatan yang dimaksud diketahui oleh wartawan adalah kejahatan yang terdapat dalam Bab VII Buku II KUHP. Sebagai contoh adalah pemberitaan mengenai pembuatan bakso berboraks. Dalam pemberitaan tersebut ditayangkan hasil wawancara dengan pelaku kejahatan, cara pembuatan bakso berboraks yang dipraktekkan oleh pelaku kejahatan, serta efek samping mengonsumsi bakso berboraks. Hasil wawancara dengan pelaku kejahatan ditayangkan dengan cara menyamarkan nama, wajah, dan suara dari pelaku kejahatan. Tindakan menyamarkan identitas pelaku kejahatan ini didasarkan pada hak tolak sebagaimana terdapat dalam Pasal 4 ayat (4) UU Pers.

Efek samping mengonsumsi bakso berboraks adalah kerusakan lambung, ginjal, muntah, kanker dan berbagai risiko kesehatan lainnya. Padahal sebagaimana yang kita ketahui bahwa mengedarkan atau menjual barang yang memiliki sifat berbahaya bagi jiwa atau kesehatan orang lain adalah kejahatan yang melanggar Pasal 204 KUHP yang menyatakan bahwa barangsiapa menjual, menawarkan, menyerahkan atau membagibagikan barang, yang diketahui bahwa membahayakan nyawa atau kesehatan orang, padahal sifat berbahaya itu tidak diberitahukan, diancam dengan pidana penjara paling lama lima belas tahun. Oleh karena kejahatan yang diberitakan oleh wartawan tersebut termasuk dalam Bab VII KUHP, yakni kejahatan yang membahayakan nyawa orang, maka berdasarkan Pasal 165 KUHP, wartawan sebagai warga negara yang baik seharusnya menindaklanjuti pemberitaan tersebut dengan melaporkan kepada kepolisan atau pejabat kehakiman. Kejahatan yang dimaksud diketahui oleh wartawan adalah kejahatan yang terdapat dalam Bab VII Buku II KUHP.Sebagai contoh adalah pemberitaan mengenai pembuatanbakso ber-boraks.

Dalam pemberitaan tersebut ditayangkan hasil wawancara dengan pelaku kejahatan, cara pembuatan bakso ber-boraks yang dipraktekkan oleh pelaku kejahatan, serta efek samping mengonsumsi bakso ber-boraks. Hasil wawancara dengan pelaku kejahatan ditayangkan dengan cara menyamarkan nama, wajah, dan suara dari pelaku kejahatan.

Tindakan menyamarkan identitas pelaku kejahatan ini didasarkan pada hak tolak sebagaimana terdapat dalam Pasal 4 ayat (4) UU Pers. Efek samping mengonsumsi bakso ber-boraks adalah kerusakan lambung, ginjal, muntah, kanker dan berbagai risiko kesehatan lainnya. Padahal sebagaimana yang kita ketahui bahwa mengedarkan atau menjual barang yang memiliki sifat berbahaya bagi jiwa atau kesehatan orang lain adalah 
kejahatan yang melanggar Pasal 204 KUHP yang menyatakan bahwa barangsiapa menjual, menawarkan, menyerahkan atau membagi-bagikan barang, yang diketahui bahwa membahayakan nyawa atau kesehatan orang, padahal sifat berbahaya itu tidak diberitahukan, diancam dengan pidana penjara paling lama lima belas tahun. Oleh karena kejahatan yang diberitakan oleh wartawan tersebut termasuk dalam Bab VII KUHP, yakni kejahatan yang membahayakan nyawa orang, maka berdasarkan Pasal 165 KUHP, wartawan sebagai warga negara yang baik seharusnya menindaklanjuti pemberitaan tersebut.

Risiko yang dapat timbul apabila wartawan tidak melakukan apa yang diwajibkan menurut KUHP dan semata-mata melakukan tindakan yang jelas dilarang demikian dapat memberikan kesan bahwa wartawan telah lebih mengutamakan kepentingan sendiri atau kepentingan golongan dengan menayangkan berita secara sensasionil sehingga mengabaikan kepentingan umum dan kewajibannya sebagai bagian dari warga Negara terhadap mana wartawan sebagai bagian dari pers juga harus mengabdikan diri.Apabila dorongan pada sensasi tersebut telah menyangkut kepentingan umum, maka persoalannya dapat menjadi serius dikarenakan akan berpotensi merugikan kepentingan umum, padahal idealnya pers harus berperan untuk memperjuangkan keadilan dan kebenaran(Lihat Pasal 6 Huruf e UU Pers).

Adapun suatu perbuatan dapat dijatuhi pidana, jika telah memenuhi unsur-unsur tindak pidana atau rumusan (delict), namun tidak selalu suatu perbuatan dapat dijatuhi pidana jika perbuatan tersebut tercantum di dalam suatu rumusan delik. Berkaitan dengan hal itu maka diperlukan syarat, bahwa perbuatan tersebut adalah perbuatan manusia, bersifat melawan hukum, dan perbuatan tersebut dapat dicela.

Simon telah merumuskan "straafbaarfeit" itu sebagai tindakan melanggar hukum yang telah dilakukan dengan sengaja ataupun tidak dengan sengaja oleh seseorang yang dapat dipertanggungjawabkan atas tindakannya dan yang oleh undang-undang telah dinyatakan sebagai suatu tindakan yang dapat dihukum(Lamintang, 2013).Oleh karena itu, penulisan ini bertujuan untuk mengetahui dan menganalaisis tindakan menyamarkan identitas kejahatan oleh wartawan menurut UU Pers dan KUHP serta penggunaan hak tolak yang tidak bertentangan dengan hukum.

\section{METODOLOGI PENELITIAN}

\section{Lokasi dan Penelitian}

Penelitian ini dilaksanakan di beberapa daerah terkait dengan pernasalahan yang dikaji. Beberapa tempat tersebut adalah Sekretariat Persatuan Wartawan Indonesia Cabang Makassar, PT Tempo Makassar. Penelitian dilakukan pada Bulan Desember 2014 hingga Februari 2015.

\section{Jenis dan Sumber Data}

Tulisan ini menggunakan jenis penelitian normatif yang didukung dengan penelitian lapangan. Penelitian normatif dilakukan terhadap berbagai peraturan perundang-undangan yang berkaitan dengan permasalah yang dikaji, seperti Undang-undang No. 40 Tahun 1999 
tentang Pers, Kitab Undang-Undang Hukum Pidana, dan peraturan lainnya yang berkiatan dengan permasalahan yang dikaji.

\section{Informan Penelitian}

Penelitian lapangan dilakukan dengan melibatkan pihak-pihak terkait dengan permasalahan yang dikaji, seperti Kepala Biro PT Tempo Makassar dan PWI Cabang Sulawesi Selatan. Data yang diperoleh dari lapangan (field research), yaitu pihak-pihak yang dianggap memiliki relevansi dan kompetensi sesuai permasalahan yang dikaji dan diperoleh melalui proses wawancara tidak berstruktur.

\section{Analisis Data}

Analisis data yang digunakan dalam penelitian ini adalah penelitian hukum normatif yang bersifat kualitatif (tidak berbentuk angka).Data yang diperoleh dan dikumpulkan dari hasil penelitian studi kepustakaan maupun wawancara disusun secara sistematis kemudian dianalisis dengan menggunakan metode analisis kualitatif. Metode analisis data adalah suatu metode dimana data yang diperoleh dari hasil penelitian dikelompokkan dan dipilih, kemudian dihubungkan dengan masalah yang akan diteliti menurut kualitas dan kebenarannya, sehingga akan dapat menjawab permasalahan yang ada. Kemudian hasil analisis dipaparkan secara deskriptif, yaitu dengan cara menjelaskan, menguraikan, dan menggambarkan permasalahan serta penyelesaiannya yang berkaitan erat dengan penulisan ini.

\section{HASIL PENELITIAN DAN PEMBAHASAN}

Wartawan dalam menjalankan profesinya berlandaskan aturan hukum yang terdapat dalam Undang-Undang No. 40 tahun 1999 tentang Pers (UU Pers)dan landasan etika profesi yang terkandung dalam Kode Etik Jurnalistik (KEJ). Tindakan menyamarkan identitas pelaku kejahatan oleh wartawan sebagaimana diketahui berpedoman pada hak tolak. Hak tolak yang dimaksud dalam Pasal 2 angka 10 UU Pers menerangkan bahwa:

Hak tolak adalah hak wartawan karena profesinya, untuk menolak mengungkapkan nama dan atau identitas lainnya dari sumber berita yang harus dirahasiakannya.

Dengan adanya ketentuan tersebut, maka wartawan mewawancarai pelaku kejahatan dengan menyamarkan nama, wajah, dan suara pelaku kejahatan dan kemudian menyiarkannya dalam pemberitaan. Tujuan seorang wartawan melakukan wawancara adalah mengumpulkan informasi yang lengkap, akurat, dan adil (fair). Secara yuridis formal, dasar pemikiran adanya hak tolak terdapat dalam Pasal 4 ayat 4 UU Pers yang menyatakan bahwa dalam mempertanggungjawabkan pemberitaan di depan hukum, wartawan mempunyai Hak Tolak.

Sudah menjadi hal yang lazim terjadi, dalam banyak pemberitaan terdapat sumber informasi yang tidak mau disebutkan identitas, keberadaan atau hubungannya dengan berita karena berbagai pertimbangan.Terhadap narasumber yang tidak mau diungkapkan 
jati dirinya, jika ada pihak yang meminta dibuka siapa sumber informasi seperti ini, undang-undang memberikan kekuatan kepada pers untuk menolak mengungkapkan narasumber ini.

Penolakan pengungkapan dari pers siapa sesungguhnya narasumber yang tidak disebutkan identitasnya dalam berita inilah yang disebut dengan hak tolak. Dalam pers seringkali dijumpai seseorang memiliki informasi yang penting untuk diketahui oleh publik karena menyangkut kepentingan publik. Bagi pers, orang semacam ini dapat dijadikan sumber informasi yang penting, tetapi terdapat kendala. Andaikan sumber ini disebut atau diungkapkan identitasnya maka narasumber menjadi tidak leluasa dalam memberikan informasi.

Ketidakleluasaan tersebut disebabkan karena narasumber merasa khawatir akan menerima sanksi hukum maupun sanksi sosial. Dengan pertimbangan itu, kemudian pers memberitakan informasi tanpa menyebut atau menyamarkan identitas narasumber. Ditinjau dari UU Pers maka tampak jelas bahwa wartawan menggunakan Hak Tolak sebagai dasar untuk melakukan tindakan menyamarkan identitas pelaku kejahatan.Tindakan wartawan yang berpedoman pada UU Pers itu bertentangan dengan Pasal 165 KUHP. Pasal 165 KUHP menerangkan bahwa:

(1) Barang siapa mengetahui ada niat untuk melakukan salah satu kejahatan berdasarkan pasal-pasal 104, 106, 107, dan 108, 110 - 113, dan 115 - 129 dan 131 atau niat untuk lari dari tentara dalam masa perang, untuk desersi, untuk membunuh dengan rencana, untuk menculik atau memperkosa atau mengetahui adanya niat untuk melakukan kejahatan tersebut dalam bab 8 dalam kitab undang-undang ini, sepanjang kejahatan itu membahayakan nyawa orang atau untuk melakukan salah satu kejahatan berdasarkan pasalpasal 224228,250 atau salah satu kejahatan berdasarkan pasal-pasal 264 dan 275 sepanjang mengenai surat kredit yang diperuntukkan bagi peredaran, sedang masih ada waktu untuk mencegah kejahatan itu, dan dengan sengaja tidak segera memberitahukan hal itu kepada pejabat kehakiman atau kepolisian atau kepada orang yang terancam oleh kejahatan itu, dipidana jika kejahatan itu jadi dilakukan, dengan pidana penjara paling lama sembilan bulan atau pidana denda paling banyak empat ribu lima ratus rupiah.

(2) Pidana tersebut diterapkan terhadap orang yang mengetahui bahwa sesuatu kejahatan berdasarkan ayat (1) telah dilakukan, dan telah membahayakan nyawa orang pada saat akibat masih dapat dicegah, dengan sengaja tidak memheritahukannya kepada pihak- pihak tersebut dalam ayat (1).

Dalam ketentuan Pasal 165 KUHP terkandung kewajiban bagi setiap warga negara untuk melaporkan setiap kejahatan yang diketahuinya kepada pihak kepolisan atau pejabat kehakiman. Sedangkan apabila kewajiban itu tidak dilakukan, maka setiap warga negara dapat dikenanakan pidana penjara sembilan bulan denda empat ribu lima ratus rupiah. Oleh karena itu, tindakan menyamarkan identitas pelaku kejahatan oleh wartawan yang berpedoman pada Hak Tolak dalam UU Pers adalah bertentangan jika dihubungkan dengan ketentuan yang diatur dalam Pasal 165 KUHP. Hal itu dikarenakan kasus-kasus kejahatan yang telah diinvestigasi dalam pemberitaan oleh wartawan termasuk dalam kejahatan yang terdapat pada Bab VII KUHP yaitu tentang Kejahatan yang Membahayakan Keamanan 
Umum Bagi Orang atau Barang. Contoh kejahatan yang telah di-investigasi oleh wartawan dalam tayangan bertema investigasi kriminal tersebut diantaranya seperti pisang ijo berbahaya, keripik balsem, minyak sayur daur ulang, ayam tiren, bumbu dapur berbahaya, bakso berboraks, jajanan anak berbahaya, bakso daging tikus, sate daging tikus, daging glonggongan. Kejahatan-kejahatan tersebut merupakan kejahatan yang diatur dalam Pasal 204 KUHP sebagaimana yang diatur dalam Pasal 165 KUHP. Dalam Pasal 204 KUHP menerangkan:

(1) Barangsiapa menjual, menawarkan, menyerahkan, atau membagi-bagikan barang, yang diketahui bahwa membahayakan nyawa atau kesehatan orang, padahal sifat berbahaya itu tidak diberitahukan, diancam dengan pidana penjara paling lama lima belas tahun.

(2) Jika perbuatan mengakibatkan matinya orang, yang bersalah dikenakan pidana penjara seumur hidup atau pidana penjara selama waktu tertentu paling lama dua puluh tahun.

Sebagaimana yang diatur dalam Pasal 165 KUHP, Pasal 204 KUHP adalah salah satu pasal yang terdapat dalam Bab VII KUHP. Sedangkan dalam tayangan bertema investigasi kriminal wartawan juga mengetahui tentang efek samping atau akibat dan bahaya dari produk serta mengkonsumsi makanan yang mengandung bahan berbahaya dan tidak layak untuk dikonsumsi.Dengan demikian, idealnya seorang wartawan sebagai warga negara Indonesia yang mengetahui adanya suatu kejahatan yang membahayakan nyawa orang seharusnya berkewajiban untuk melaporkan atau memberitahukan kejahatan tersebut kepada pejabat kehakiman atau kepolisian.

UU Pers merupakan Lex Spesialis berdasarkan Putusan Mahkamah Agung Nomor 1608K/PID/2005 tanggal 9 Februari 2006. Pada kenyataannya walaupun telah ditegaskan sebagai lex specialis, namun hingga saat ini masih terjadi perdebatan dikarenakan banyak praktisi hukum termasuk hakim, penyidik, dan polisi cenderung mengganggap bahwa UU Pers terlalu luas sehingga menimbulkan celah hukum (loopholes) yang dapat digunakan oleh pers untuk melakukan hal-hal yang sebenarnya bertentangan dengan KUHP sebagai lex generalis.

Sedangkan Asas lex specialis derogat legi generali yang diatur dalam Pasal 63 ayat (2) KUHP menyatakan bahwa jika suatu perbuatan masuk dalam suatu aturan pidana yang umum, diatur pula dalam aturan pidana yang khusus, maka hanya yang khusus itulah yang diterapkan.

Menurut penulis, pro dan kontra UU Pers sebagai lex specialis dalam kaitannya dengan tindakan menyamarkan identitas pelaku kejahatan oleh wartawan tetap tidak mempengaruhi tindakan menyamarkan identitas pelaku kejahatan oleh wartawan. Hal itu dikarenakan penggunaan hak tolak dalam UU Pers terhadap narasumber yang merupakan pelaku kejahatan tidak diatur dalam UU Pers. Oleh sebab itu, KUHP tetap dapat dijadikan acuan sehingga insan pers tetap dapat dikategorikan melanggar Pasal 165 KUHP.

Apabila wartawan melakukan tindakan menyamarkan identitas pelaku kejahatan yang telah nyata bertentangan dengan KUHP, sedangkan di satu sisi dengan melindungi begitu banyak pelaku kejahatan disadari akibat yang akan timbul adalah kerugian bagi 
kepentingan umum yang lebih besar maka hal ini akan menjadi sutu potensi permasalahan. Jika dibiarkan begitu saja dengan alasan tersebut, maka wartawan sebagai bagian dari pers seolah-olah memiliki kekebalan hukum. Padahal wartawan sebagai bagian dari pers juga berkedudukan sebagai warga negara yang berarti bahwa wartawan juga memilki hak dan kewajiban yang sama di depan hukum. Selain itu, dalam tataran ideal pekerjaan jurnalistik mengatur pula bahwa wartawan wajib mengabdikan diri kepada kepentingan sosial dan bukan finansial semata di era komersialisasi pers yang menjadikan pers memiliki fungsi ganda sebagai lembaga sosial dan lembaga ekonomi.

Tertib hukum hanya dapat diperoleh bila hukum itu sendiri dapat juga menjaga adanya freedom of individual dan protection of thecommunity, antara kebebasan dan kontrol sosial sekaligus menjaminadanya persamaan hak dan kewajiban bagi setiap orang menurut undang undang (Equal justice under the law) terlebih wartawan sebagai bagian dari pers merupakan salah satu pilar ke-empat negara demokrasi.Bahkan Kovach menyatakan bahwa salah satu intisari jurnalisme adalah loyalitasnya pada publik. Hal ini juga sesuai dengan prinsip hukum tentang prinsip persamaan kedudukan dalam hukum dan pemerintahan yang terkandung di dalam UUD 1945 Pasal 27 ayat (1) bahwa segala warga negara bersamaan kedudukannya di dalam hukum dan pemerintahan dan wajib menjunjung hukum dan pemerintahan itu dengan tidak ada kecualinya.

Jika dikaji lebih jauh dari UU Pers sendiri, kewajiban bagi wartawan untuk memberitahukan kejahatan yang diketahuinya kepada pejabat kehakiman atau kepolisian juga tersirat dalam Pasal 6 huruf e UU Pers yang menyatakan bahwa Pers melaksanakan peranan memperjuangkan keadilan dan kebenaran.

Dengan adanya peranan pers tersebut diharapkan supremasi hukum dapat terwujud guna menciptakan masyarakat yang tertib sebagaimana dinyatakan dalam Penjelasan Pasal 6 UU Pers yang menerangkan bahwa pers nasional mempunyai peranan penting dalam memenuhi hak masyarakat untuk mengetahui dan mengembangkan pendapat umum, dengan menyampaikan informasi yang tepat, akurat dan benar. Hal ini akan mendorong ditegakkannya keadilan dan kebenaran, serta diwujudkannya supremasi hukum untuk menuju masyarakat yang tertib. Tindakan menyamarkan identitas pelaku kejahatan oleh wartawan dapat diartikan bahwa wartawan mengetahui adanya suatu kejahatan namun tidak menindaklanjutinya dengan melaporkan kejahatan yang diketahuinya kepada pejabat kehakiman atau kepolisian, secara tidak langsung menunjukkan bahwa wartawan sebagai bagian dari pers tidak melaksanakan peranan yang diamanatkan untuk memperjuangkan kebenaran dan keadilan serta tujuan pers untuk mewujudkan supremasi hukum dan mewujudkan masyarakat yang tertib tidak akan dapat tercapai.

Jika ditinjau dari segi hukum pidana maka perbuatan wartawan memenuhi doktrin rumusan tindak pidana menurut Simons. Simons merumuskan untuk adanya suatu tindak pidana harus dipenuhi unsur-unsur berikut:

1. Perbuatan manusia, baik dalam arti perbuatan positif (berbuat) maupun perbuatan negatif (tidak berbuat);

2. Diancam dengan pidana;

3. Melawan hukum;

4. Dilakukan dengan kesalahan;dan

5. Oleh orang yang mampu bertanggung jawab. 
Perbuatan manusia dalam hal ini seorang atau beberapa wartawan dengan perbuatan negatif yakni tidak berbuat yang diharuskan dalam Pasal 165 KUHP, tindakan tersebut adalah perbuatan yang diancam dengan pidana sebagaimana terdapat dalam Pasal 165 KUHP. Bersifat melawan hukum karena dilakukan dengan sengaja dalam arti mengetahui suatu kejahatan tetapi tidak memberitahukannya kepada pejabat kehakiman atau kepolisian, melawan hukum diartikan pula sebagai bertentangan dengan hukum yakni Pasal 165 KUHP. Kesalahan dianggap ada apabila dengan sengaja atau karena kelalaian telah melakukan perbuatan yang menimbulkan keadaan atau akibat yang dilarang oleh hukum pidana. Kemampuan bertanggung jawab oleh wartawan dikarenakan wartawan adalah tidak termasuk dalam ketentuan sesuai yang dimaksud Pasal 44 KUHP yaitu barang siapa melakukan perbuatan yang tidak dapat dipertanggungkan kepadanya karena jiwanya cacat dalam pertumbuhan atau terganggu.

Pertanggungjawaban pidana dipandang ada, kecuali ada alasan penghapus pidana. Pertanggungjawaban pidana menjurus kepada pemidanaan petindak, jika telah melakukan suatu tindak pidana dan memenuhi unsur-unsurnya yang telah dilakukan dalam undangundang. Dilihat dari sudut terjadi suatu tindakan yang terlarang (diharuskan), seseorang akan dipertanggungjawab-pidanakan atas tindakan-tindakan tersebut apabila tindakan tersebut bersifat melawan hukum untuk itu. Dilihat dari sudut kemampuan bertanggungjawab maka hanya seseorang mampu bertanggungjawab yang dapat dipertanggungjawab-pidanakan. Mempertanggungjawabkan seseorang dalam hukum pidana bukan hanya berarti sah menjatuhkan pidana terhadap orang itu, tetapi juga sepenuhnya dapat diyakini bahwa memang pada tempatnya meminta pertanggungjawaban atas tindak pidana yang dilakukannya (Ilyas, 2012).

Pertanggungjawaban pidana adalah pertanggungjawaban terhadap tindak pidana yang dilakukannya.Tegasnya, yang dipertanggungjawabkan orang itu adalah tindak pidana yang dilakukannya. Dengan demikian, terjadinya pertanggungjawaban pidana karena telah ada tindak pidana yang dilakukan oleh seseorang. Pertanggungjawaban pidana pada hakikatnya merupakan suatu mekanisme yang dibangun oleh hukum pidana untuk bereaksi terhadap pelanggaran atas kesepakatan menolak suatu perbuatan tertentu.Tindakan menyamarkan identitas pelaku kejahatan oleh wartawan memenuhi sifat tindak pidana yang berupa membahayakan suatu kepentingan hukum concrete gevaarzettingsdelicten.

Kejahatan yang dimaksud adalah membahayakan keamanan umum bagi orang yang diatur dalam Pasal 204 KUHP, hal ini menunjukkan bahwa secara tidak langsung wartawan telah menyembunyikan pelaku kejahatan yang melanggar Pasal 204 KUHP sedangkan tindakan wartawan tersebut dapat membahayakan keamanan umum bagi orang. Adapun suatu perbuatan dapat dijatuhi pidana maka diperlukan beberapa syarat, yakni:

1. Perbuatan tersebut adalah perbuatan manusia, dalam hal ini adalah perbuatan insan pers di mana perbuatan tersebut sudah dilakukan yang terwujud dalam acara televisi serta pelakunya (wartawan) dapat dipertanggungjawabkan, artinya orang atau pelaku tindak pidana secara mental dan fisik dapat mempertanggungjawabkan (Pasal $44 \mathrm{KUHP}$ ).

2. Bersifat melawan hukum, perbuatan wartawan tersebut bersifat melawan hukum formil karena telah memenuhi unsur-unsur dalam Pasal 165 KUHP sehingga 
perbuatan tersebut menjadi dapat dipidana.

3. Perbuatan tersebut dapat dicela, perbuatan insan pers tersebut bersifat melawan hukum dan dapat dicela yang merupakan syarat umum untuk dapat dipidananya suatu perbuatan.

4. Diancam dengan pidana, sebagai syarat untuk menindak terhadap suatu perbuatan yang tercela yaitu adanya suatu ketentuan dalam undang-undang pidana yang merumuskan perbuatan yang tercela itu dan memberikan suatu sanksi terhadapnya, ini disebut legalitas negara dalam hukum pidana (Prasetyo, 2011).

Unsur dari tindak pidana yang dipenuhi dalam perbuatan insan pers tersebut adalah perbuatan yang dilarang, akibat dari perbuatan itu yang menjadi dasar alasan mengapa perbuatan itu dilarang, dan sifat melanggar hukum dalam rangkaian sebab musabab itu. Perbuatan yang dilarang adalah perbuatan menyamarkan identitas pelaku kejahatan tanpa kemudian memberitahukannya kepada pejabat kehakiman atau kepolisian sebagaimana dinyatakan dalam Pasal 165 KUHP yang mencakupi asas legalitas.

Asas legalitas mengandung makna bahwa ketentuan dapat dipidananya suatu perbuatan harus terjadi melalui undang-undang yang dibuat oleh negara dalam arti formal atau berdasarkan ketentuan undang-undang dalam arti formal. Asas ini tercantum dalam Pasal 1 ayat (1) KUHP dengan rumusan: "Geen feil is strafbaar dan uti kracht van eenedaaraan vooragegane wettlejike strafbepalingen" atau "Suatu perbuatan tidak dapat dipidana, kecuali berdasarkan kekuatan ketentuan peraturan perundang-undangan pidana yang telah ada".

Akibat perbuatan itu adalah membahayakan nyawa orang sehingga menjadi dasar alasan kenapa perbuatan itu dilarang. Sifat melawan hukum dari perbuatan insan pers tersebut adalah mengetahui suatu kejahatan yang telah dilakukan, pada saat kejahatan masih dapat dicegah dengan sengaja tidak memberitahukannya kepada pejabat kehakiman atau kepolisian. Ditinjau dari jenis tindak pidananya, maka tindakan wartawan tersebut termasuk dalam jenis tindak pidana berupa delik formal, delik omisi, dan delik dolus.

Delik formal adalah delik yang dianggap selesai dengan dilakukannya suatu perbuatan, atau dengan kata lain titik beratnya ada pada perbuatan itu sendiri. Dalam hal ini wartawan tidak melakukan suatu tindakan yang menjadi kewajiban oleh undang-undang ataupun sesuatu yang diwajibkan oleh undang-undang, dalam hal ini adalah kewajiban melaporkan delik yang diatur dalam Pasal 165 KUHP. Seseeorang yang dipandang sebagai seorang pelaku dalam delik formal adalah orang yang melakukan pelanggaran dalam hal ini wartawan terhadap keharusan atau kewajiban yang telah disebutkan dalam undangundang Pasal 165 KUHP. Sedangkan delik omisi Delik omisi ialah delik yang dilakukan dengan tidak melakukan suatu perbuatan yang diharuskan oleh undang-undang.Perbuatan itu adalah tidak memberitahukan adanya suatu kejahatan kepada pejabat kehakiman dan kepolisian. Delik dolus (sengaja) adalah delik yang memuat unsur kesengajaan. Dalam hal ini, wartawan mengetahui tentang adanya suatu kejahatan yang telah dilakukan yakni kejahatan yang diatur dalam Pasal 204 KUHP dan mengetahui bahwa akibatnya dapat membahayakan nyawa orang, pada saat kejahatan masih dapat dicegah atau masih ada tempo untuk mencegahnya namun dengan sengaja tidak memberitahukannya kepada pejabat kehakiman atau kepolisian. 
Kemungkinan tindak pidana dari perbuatan wartawan tersebut adalah mengetahui suatu kejahatan tetapi tidak melaporkan kepada yang berwajib dan pembantuan yang pasif dalam arti luas.Dikategorikan sebagai pembantuan yang pasif dalam arti luas adalah karena menurut masyarakat luas, semua orang harus melakukan pencegahan terhadap terjadinya suatu delik. Perbuatan insan pers juga memenuhi rumusan Pasal 165 KUHP. Pertama, adalah unsur barangsiapa, yaitu wartawan. Kedua, unsur mengetahui niat untuk melakukan kejahatan tersebut dalam Bab VII Kitab Undang-undang ini, yaitu mengetahui suatu kejahatan yang tercantum dalam Pasal 204 KUHP (Bab VII Buku II). Kedua, sepanjang kejahatan itu membahayakan nyawa orang, yaitu kejahatan-kejahatan seperti membuat dan menjual makanan yang telah dicampuri zat berbahaya adalah kejahatan yang membahayakan nyawa atau kesehatan orang.

Ketiga, pada saat kejahatan masih dapat dicegah dengan sengaja tidak memberitahukan kepada pejabat kehakiman atau kepolisian, yaitu insan pers mengetahui adanya kejahatan Pasal 204 KUHP telah dilakukan, tetapi dengan segaja tidak melaporkannya. Jika Pasal 165 KUHP dihadapkan dengan hak tolak, maka yang dapat dijadikan landasan adalah penggunaan hak tolak terhadap narasumber yang adalah saksi, korban kejahatan susila, serta anak di bawah umur yang menjadi pelaku kejahatan sesuai dengan ketentuan yang diatur dalam Pasal 5 dan Pasal 7 Kode Etik Jurnalistik.

Kode Etik Jurnalistik mencantumkan hak tolak dalam Pasal 5 dan Pasal 7. Pasal 5 menyatakan bahwa :

"Wartawan Indonesia tidak menyebutkan dan menyiarkan identitas korban kejahatan susila dan tidak menyebutkan identitas anak yang menjadi pelaku kejahatan."

Pasal 7 Kode Etik Jurnalistik menyatakan bahwa :

Wartawan Indonesia memiliki hak tolak untuk melindungi narasumber yang tidak bersedia diketahui identitas maupun keberadaannya, menghargai ketentuan embargo, informasi latar belakang, dan off the record sesuai dengan kesepakatan.

Berdasarkan pengaturan hak tolak tersebut, di dalam UU Pers terlihat jelas bahwa penggunaan hak tolak merupakan celah bagi insan pers untuk menyamarkan identitas pelaku kejahatan yang menjadi narasumbernya. Dalam Pasal 5 Kode Etik Jurnalistik menyebutkan bahwa wartawan menggunakan hak tolak untuk identitas korban kejahatan susila dan identitas anak pelaku kejahatan sedangkan di dalam Pasal 7 Kode Etik Jurnalistik hanya disebutkan wartawan Indonesia memiliki hak untuk melindungi narasumber yang tidak bersedia diketahui identitas maupun keberadaannya, jenis narasumber yang berhak disamarkan identitasnya tidak disebutkan dalam Pasal tersebut.

Dari hal tersebut maka sesungguhnya tampak adanya celah hukum (loopholes) dalam UU Pers yang digunakan oleh wartawan untuk dapat menjadi suatu pelanggaran terhadap KUHP, khususnya Pasal 165 KUHP adalah mengenai hak tolak. Hak tolak dalam Pasal 4 ayat (4) UU Pers dinyatakan bahwa dalam mempertanggungjawabkan pemberitaan di depan hukum, wartawan mempunyai Hak Tolak. 
Sesuai Penjelasan Pasal 4 UU Pers, dapat diartikan bahwa wartawan telah menggunakan hak tolak untuk melindungi sumber informasi, yakni termasuk melindungi sumber informasi yang juga merupakan seorang pelaku kejahatan. Hal itu dikarenakan tidak adanya pengaturan dalam UU Pers yang menentukan siapa-siapa saja yang dimaksud sebagai sumber informasi.Bahkan dikarenakan adanya penafsiran yang sangat luas atas sumber informasi yang diatur dalam pasal tersebut, maka konsekuensinya adalah ketika seorang wartawan menjalankan profesinya dengan kemudian melindungi atau menyamarkan identitas sumber informasinya yang merupakan seorang pelaku kejahatan, maka yang dapat terjadi adalah risiko terjadinya pelanggaran terhadap KUHP khususnya Pasal 165.

Beberapa kasus kejahatanan yang telah diinvestigasi oleh insan pers adalah telur ayam kampung palsu, telur asin palsu, kosmetik palsu, daging sapi glonggongan, dan bakso tikus (seperti yang telah dijabarkan pada Bab sebelumnya).Insan pers tersebut telah melakukan wawancara langsung dengan narasumber (pelaku kejahatan) dan menyamarkan identitas pelaku kejahatan tersebut dalam hasil tayangan program investigasi.Perbuatan insan pers tersebut telah melanggar Pasal 165 KUHP karena insan pers sebagai warga negara yang mengetahui adanya suatu kejahatan yang telah dilakukan, tidak melaporkan kejahatan tersebut kepada pejabat kehakiman atau kepolisian. Insan pers yang melanggar Pasal 165 KUHP tersebut terkena sanksi dengan pidana penjara paling lama 9 (sembilan) bulan atau pidana denda paling banyak empat ribu lima ratus rupiah. Kewajiban bagi wartawan untuk memberitahukan kejahatan yang diketahuinya kepada pejabat kehakiman atau kepolisian juga tersirat dalam Pasal 6 huruf e UU Pers yang menyatakan bahwa Pers melaksanakan peranan memperjuangkan keadilan dan kebenaran.

Menurut Iswandi Syahputra (2013), ketika pers melemparkan sebuah isu sebagai pemberitaan maka ia bertanggungjawab penuh atas penyelesaian dari isu tersebut. Dari hal itu dapat diartikan bahwa ketika pers mengetahui adanya suatu kejahatan maka wajib berlaku baginya hukum yang sama terhadap hukum yang juga berlaku bagi warga negara lainnya mengingat kedudukan wartawan yang juga sebagai bagian dari pers sekaligus merupakan warga negara. Pers bukan kelompok elite dalam negara yang terpisah dari kepentingan publik.Pers juga bukan kelompok masyarakat yang memiliki hak istimewa dan kebal dengan hukum, terlebih pers penyiaran menggunakan frekuensi milik publik. intisari jurnalisme terletak pada idealisme wartawan atas loyalitasnya terhadap masyarakat dan negara dalam bentuk menaati segala tertib hukum dan bukan semata-mata kehendak redaksi yang beroirentasi finansial. Lebih lanjut beliau menyatakan bahwa idealisme jurnalistik di era saat ini ketika jurnalisme telah bersifat ekonomis dan komersil tidak dapat dijadikan jaminan bahwa semua wartawan memiliki sikap idealisme.Mencermati hal itu maka dangkalnya pemahaman tentang kebebasan media ini sering terwujud dalam bentuk kehidupan pers yang sulit diatur seperti saat ini (Hasil wawancara dengan pengurus PWI Kota Makassar, 2015).

\section{KESIMPULAN DAN SARAN}

Penafsiran atas Hak Tolak yang sangat luas adalah celah hukum yang digunakan oleh wartawan untuk melakukan tindakan menyamarkan identitas pelaku kejahatan. 
Tindakan menyamarkan identitas pelaku kejahatan oleh wartawan bertentangan dengan Pasal 165 KUHP yang mewajibkan bagi setiap warga negara untuk melaporkan kejahatan yang diketahuinya kepada pihak kepolisian dan pejabat kehakiman. Penggunaan Hak Tolak wartawan yang tidak bertentangan dengan Pasal 165 KUHP hanya dapat digunakan untuk menyamarkan identitas sumber informasi yang merupakan saksi, pelaku kejahatan anak, dan korban kejahatan susila seperti yang diatur dalam Kode Etik Jurnalistik. Meskipun demikian, wartawan dalam menjalankan profesinya seharusnya patut menduga kedudukannya sebagai wartawan tidak membuat nya menjalankan profesi tanpa memerhatikan aturan hukum lain. Hal itu dikarenakan, pers bukanlah sebuah lembaga yang kebal hukum. Pers memang diberi kebebasan, namun tidak ada kebebasan yang absolut ketika kebebasan itu bertenatangan dengan kebebasan lain. Selain itu, wartawan sebagai bagian dari pers merupakan pilar demokrasi di Indonesia maka sudah seyogyanya pers senantiasa memerhatikan setiapa akibat yang mungkin akan ditimbulkan dari tindakannya.

\section{DAFTAR PUSTAKA}

Ilyas, Amir. 2012. Asas-Asas Hukum Pidana. Yogyakarta: Rangkang Education.

Huda, Chairul. 2006. Dari Tiada Pidana Tanpa Kesalahan Menuju Kepada Tiada Pidana tanpa Kesalahan. Jakarta: Kencana Prenada Media.

Lamintang. 2013. Dasar-Dasar Hukum Pidana Indonesia. Bandung: PT. Citra Karya Abadi.

Marlang, Abdullah dan Irwansyah. 2007. Pengantar Hukum Indonesia. Buku Ajar Fakultas Hukum. Makassar: Universitas Hasanuddin.

Prasetyo, Teguh. 2011. Kriminalisasi Dalam Hukum Pidana. Bandung: Nusa Media.

R. Soesilo. KUHP. Bogor: Politea.

Siregar, Amir Effendy. 2003. Kebebasan Pers dan Kode Etik Jurnalistik, Yogyakarta. UII Press.

Syahputra, Iswandi. 2013. Rezim Media. Jakarta: PT. Gramedia Pustaka Utama. 